\title{
Cell Growth of Ovarian Cancer Cells is Stimulated by Xenoestrogens through an Estrogen-Dependent Pathway, but Their Stimulation of Cell Growth Appears not to be Involved in the Activation of the Mitogen- Activated Protein Kinases ERK-1 and p38
}

\author{
Se-Hyung PARK ${ }^{1) *}$, Ki-Yon $\mathrm{KIM}^{1) *}$, Beum-Soo AN ${ }^{1)}$, Jung-Hye $\mathrm{CHOI}^{1)}$, Eui-Bae JEUNG ${ }^{2)}$, \\ Peter C. K. LEUNG ${ }^{1)}$ and Kyung-Chul $\mathrm{CHOI}^{1,2)}$ \\ ${ }^{1)}$ Department of Obstetrics and Gynecology, British Columbia Women's Hospital, Child and Family Research Institute, \\ University of British Columbia, Vancouver, British Columbia V6H 3V5, Canada and ${ }^{2)}$ Laboratory of Veterinary \\ Biochemistry and Molecular Biotechnology, College of Veterinary Medicine, Chungbuk National University, Cheongju, \\ Chungbuk, Korea
}

\begin{abstract}
Although endocrine disrupting chemicals (EDCs) may interfere with the endocrine system(s) of our body and have estrogenicity or androgenicity, the exact mechanism(s) underlying their detrimental effects is not clearly understood. Thus, in this study, we evaluated the effects of EDCs on proliferation and regulation of transcription of estrogen receptor (ER)-positive BG-1 ovarian cancer cells, and their possible mechanisms were further examined. Treatment with bisphenol A (BPA), nonylphenol (NP), octylphenol (OP) and methoxychlor (MXC) for 24 h resulted in an increase of cell proliferation. Treatment with BPA, NP, OP and MXC increased the estrogen response element (ERE) activity. The increase of cell proliferation and activation of ERE were reversed in the presence of an estrogen receptor antagonist, ICI 182780. These results suggest that ER is involved in EDC-mediated pathway in ovarian cancer cells. Based on this, we further investigated the involvement of EDCs in activation of mitogen-activated protein kinase (MAPK) in relation to cell growth. BPA rapidly induced activation of extracellular signal-regulated kinase (ERK) $1 / 2$ and p38 MAPK at $15 \mathrm{~min}$, but the effect of BPA $(10 \mu \mathrm{M})$ on stimulation of cell growth was not blocked by pretreatment with inhibitors of MEK (PD98059) or p38 (SB203580) in a dose-dependent manner. Taken together, EDC-induced proliferation is mediated by a genomic effect through ERs and ERE, but EDC-activated MAPK is unlikely to be involved in EDC-induced cell growth in estrogen-responsive ovarian cancer cells.
\end{abstract}

Key words: Endocrine disrupting chemical, Estrogen receptor, Estrogen response element, Extracellular signalregulated kinase, Mitogen-activated protein kinase

(J. Reprod. Dev. 55: 23-29, 2009)

0 varian carcinoma is one of the most frequent gynaecologic cancers, following breast, lung and colorectal cancer [1]. Although the biological causes of ovarian cancer remain unknown, hormonal factors such as estrogen or gonadotropins have been implicated in the etiology of ovarian cancer [2]. In addition, it has been reported that endocrine disrupting chemicals (EDCs) may increase the risk of cancer incidence [3, 4]. However, the data associated with the effect of EDCs on ovarian cancer cells are scarce.

Since EDCs are known as environmental chemicals that interfere with the hormonal balance of vertebrates and invertebrates, they are considered to be important in physiology and the endocrine system [5, 6]. EDCs are released from industrial products such as plastics, pesticides, detergents and other synthetic products. It has been proposed that EDCs may increase human health risks and have potentials to affect the immune system and development of vital organs [7-9].

Bisphenol-A (BPA), alkylphenols, dichloro-diphenyl-trichloro-

Accepted for publication: September 6, 2008

Published online in J-STAGE: October 15, 2008

*These authors contributed equally to this work.

Correspondence: KC Choi (e-mail: kchoi@cbu.ac.kr, kchoi@cw.bc.ca) ethane (DDT), polychlorinated biphenyls (PCBs) and phthalates are mainly highlighted among EDCs. BPA, a compound used in polycarbonate and epoxy resins, has been implicated as a potent risk factor for women's health [10]. BPA has been widely used in plastic products, such as drinking water containers, dental sealants and coating materials to prevent corrosion on the inner surfaces of metal food containers, and is released from plastic containers under normal conditions of use; the leaching of BPA is facilitated by high temperatures [11]. Exposure to BPA is even possible by contact with swallowed dust [12], and even this type of exposure exerts xenoestrogen action [13]. Methoxychlor (MXC), a synthetic pesticide, has been used as a replacement for DDT and is considered to be a xenoestrogen that disrupts the reproductive system [14]. In addition, 4-alkylphenol ethoxylates (APEs) are widely used as surfactants in lubricant oil addictives, phosphate antioxidants and rubber products [15], and they have been shown to have an estrogenic effect [16]. Furthermore, the metabolites of APEs, such as nonylphenol (NP) and octylphenol (OP), exhibit an estrogenic effect at low concentrations [5, 17]. They are known as toxic contaminants and can be found in indoor/outdoor air and in the aquatic environment $[18,19]$.

Based on these previous studies, we further examined the effects 
of EDCs on cell proliferation and the activation of estrogen response element (ERE) in an E2-dependent ovarian cancer cell line, BG-1. In addition, possible mechanisms of EDCs involved in cell proliferation were subsequently investigated.

\section{Materials and Methods}

\section{Cells and cell culture}

BG-1 and A2780 human ovarian cancer cells were provided by Dr. KS Korach (National Institute of Environmental Health Sciences, NIH, Research Triangle Park, NC, USA) and obtained from ECACC (Porton Down, UK), respectively. Cells were cultured in DMEM/F12 mixture (Sigma-Aldrich, St. Louis, MO, USA) supplemented with 10\% FBS (HyClone, Logan, UT, USA), $100 \mathrm{U} / \mathrm{ml}$ penicillin $\mathrm{G}$ and $100 \mu \mathrm{g} / \mathrm{ml}$ streptomycin (Life Technologies, Rockville, MD, USA) at $37 \mathrm{C}$ in a humidified atmosphere of $5 \%$ $\mathrm{CO}_{2}-95 \%$ air.

\section{Preparation of plasmid constructs}

The reporter plasmid ERE2-tk109-Luc was provided by Dr. JL Jameson (Division of Endocrinology, Metabolism, and Molecular Medicine, Northwestern University Medical School, Chicago, IL, USA) as previously used [20]. The study of transfection was performed using plasmid DNAs prepared using Plasmid Maxi Kits (Qiagen, Chatsworth, CA, USA) following the manufacturer's suggested procedure. The concentration of DNA was measured by absorbance at $260 \mathrm{~nm}$, and the integrity of plasmid DNA was determined by agarose gel electrophoresis. Purified plasmid DNAs were then dissolved $0.1 \times$ TE $(1 \mathrm{mM}$ Tris-Cl; $\mathrm{pH}$ 7.5, $0.1 \mathrm{mM}$ EDTA).

\section{Transient transfection and reporter assay}

Transient transfection was performed using FuGENE 6.0, according to the manufacturer's procedure (Roche Diagnostics, Laval, Quebec, Canada). To correct for the different transfection efficiencies of various luciferase constructs, the Rous sarcoma virus (RSV)-lacZ plasmid was co-transfected into the cells. BG-1 cells were seeded at a density of $4 \times 10^{5}$ into six-well tissue culture plates in $2 \mathrm{ml}$ phenol red-free DMEM (Life Technologies) containing 10\% charcoal-dextran-treated FBS (HyClone) before the day of transfection. One $\mu \mathrm{g}$ of the ERE promoter-luciferase construct, 0.5 $\mu \mathrm{g}$ RSV-lacZ and an indicated amount of expression plasmids were dissolved in $100 \mu \mathrm{l}$ phenol red-free DMEM containing $3 \mu \mathrm{l}$ FuGENE 6.0. The DNA mixture was incubated for $45 \mathrm{~min}$ at room temperature and then applied to the cells. Incubation of the cells with transfection medium continued for approximately $24 \mathrm{~h}$ at $37 \mathrm{C}$ in $5 \% \mathrm{CO}_{2}$. After 24 -h transfection, the cells were treated with various concentrations of $17 \beta$-estradiol (E2), BPA, MXC, OP, or NP at different time concentrations before harvest. Ethanol was added to the control media at the same final solvent concentration (typically $0.1 \%$ ). The cellular lysates were collected with $150 \mu \mathrm{l}$ reporter lysis buffer (Promega, Nepean, Canada) and cell lysis buffer and were assayed for luciferase activity and $\beta$-galactosidase activity immediately with the Luciferase Assay and $\beta$-Galactosidase Enzyme Assay Systems (Promega). Luminescence was measured using a Lumat LB 9507 luminometer (EG\&G, Berthold,
Germany). $\beta$-Galactosidase activity was also measured and used to normalize for varying transfection efficiencies. Promoter activity was calculated as luciferase activity/ $\beta$-galactosidase activity. A promoterless pGL2-Basic vector was included as a control in the transfection experiments.

\section{Immunoblot analysis}

An immunoblot assay was performed to identify the expression of ER $\alpha$ and ER $\beta$ in BG- 1 cells. Thirty $\mu$ g of total protein was run on a $10 \%$ SDS-PAGE gel and transferred to a nitrocellulose membrane. The membrane was immunoblotted using a mouse monoclonal antibody for ER $\alpha$ (Santa Cruz Biotechnology, Santa Cruz, CA, USA) and ER $\beta$ (Abcam, Cambridge, MA, USA). The membrane was immunoblotted using the actin antibody (Santa Cruz Biotechnology). To investigate the effect of xenoestrogen on activation of MAPK, approximately $1 \times 10^{6}$ cells were washed twice with ice-cold PBS and lysed in $100 \mu$ of ice-cold RIPA buffer (containing $1 \times$ PBS [pH 7.4], 1\% NP 40, 0.5\% sodium deoxycholate, $0.1 \%$ SDS, $10 \mathrm{mg} / \mathrm{ml}$ phenylmethylsulfonyl fluoride, $30 \mathrm{mg} / \mathrm{ml}$ aprotinin and $10 \mathrm{mg} / \mathrm{ml}$ leupeptin) for $15 \mathrm{~min}$ on ice. The protein concentration was determined using the Bradford assay (Bio-Rad Laboratories, Mississauga, ON, Canada). The protein solution was then subjected to electrophoresis on a $10 \%$ SDSPAGE and electrotransferred to a nitrocellulose membrane (Hybond C; Amersham Pharmacia Biotech, Oakville, ON, Canada). The membrane was immunoblotted with a rabbit polyclonal antibody for phosphorylated p38 MAPK (Biosource International, Camarillo, CA, USA), a mouse monoclonal antibody for phosphorylated extracellular signal-regulated kinase ERK 1/2 (New England Biolabs, Pickering, ON, Canada) and a protein molecular marker (New England Biolabs). After washing three times with TBS-T (0.1\% Tween-20 in TBS) for $15 \mathrm{~min}$, the signals were detected with horseradish peroxidase-conjugated secondary antibody (Amersham Pharmacia Biotech) and were visualized using an ECL chemiluminescent system (Amersham Pharmacia Biotech). Alternatively, the membrane was probed with a mouse monoclonal p38 MAPK antibody (Biosource International) and pan ERK1/2 (New England Biolabs), which detects the total p38 MAPK and ERK1/2 levels, respectively.

\section{Thymidine incorporation assay}

A proliferation assay was performed using the $\left[{ }^{3} \mathrm{H}\right]$ thymidine incorporation assay as previously described [21]. Briefly, BG-1 cells $\left(4 \times 10^{4}\right)$ were plated in 24 -well dishes in $0.5 \mathrm{ml}$ of medium as described above. After incubation for $24 \mathrm{~h}$, the cells were washed once with no FBS media and incubated in 5\% charcoal-dextran treated FBS for 1 day. The cells were then treated with E2 or xenoestrogen in a different time-dependent manner for $24 \mathrm{~h}$. Following treatment, the cells were incubated with medium containing $1 \mu \mathrm{Ci}\left[{ }^{3} \mathrm{H}\right]$ thymidine $(0.5 \mathrm{Ci} / \mathrm{mmol}$; Amersham Pharmacia Biotech) and collected $24 \mathrm{~h}$ later. In order to block the genomic estrogen signaling pathway, the cells were pretreated with ICI 182780 (100 nM; Calbiochem, San Diego, CA, USA) and then treated with E2 and xenoestrogen. In order to block the effect of ERK1/2 and p38 MAPK, the cells were pretreated with PD98059 or SB203580 for 1 $\mathrm{h}$ and then treated with E2 and xenoestrogen. The control culture 
$\mathbf{E R} \alpha$

Actin

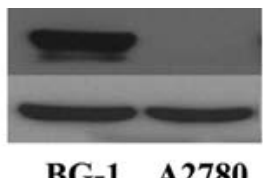

ER $\beta$

Actin

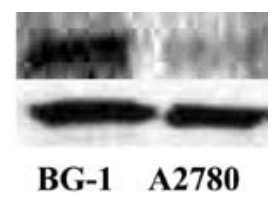

Fig. 1. Protein expression of $\mathrm{ER} \alpha$ in the estrogen-responsive ovarian cancer cell line BG-1. The protein was isolated and prepared as described in the Materials and Methods. The protein level of ER $\alpha$ was examined by Western blot analysis by using an ER $\alpha$ monoclonal antibody. Western blot analysis showed a specific band at a molecular weight of 68-KDa in the BG-1 cells. An ER $\alpha$ negative ovarian cancer cell line, A2780, was employed as a control.

was treated with vehicle. The cells were precipitated with $0.5 \mathrm{ml}$ trichloroacetic acid (10\%) for $20 \mathrm{~min}$ at $4 \mathrm{C}$. The precipitate was washed in methanol twice and solubilized in $0.5 \mathrm{ml}$ sodium hydroxide $(0.1 \mathrm{~N})$. The radioactivity was measured in a Tri-Carb Liquid Scintillation Analyzer (Model 2100TR; Packard Instrument Com., Meriden, CT, USA).

\section{Data analysis}

Data are presented as means \pm SD. The data were analyzed by ANOVA followed by Tukey's multiple comparison test. $\mathrm{P}<0.05$ was considered statistically significant.

\section{Results}

\section{Confirmation of expression of ER $\alpha$ and $E R \beta$ in BG-1 cells}

Since the ovarian adenocarcinoma cell line BG-1 is well known for its expression of ER $\alpha$ [22], we first confirmed expression of $\mathrm{ER} \alpha$ by Western blot analysis using an antibody targeting ER $\alpha$ in BG-1 cells. ER $\alpha$ is expressed in BG-1 cells, but is not expressed in the ER $\alpha$-negative ovarian cancer cell line A2780 (Fig. 1). We further confirmed the expression of $\operatorname{ER} \beta$ in BG- 1 cells and demonstrated that $\mathrm{ER} \beta$ protein is also expressed in $\mathrm{BG}-1$ cells.

\section{Proliferative effect of EDCs on ovarian cancer cells}

To determine the effect of E2 and EDCs on cell proliferation, BG-1 cells were treated with increasing doses of E2 and EDCs. Treatment with EDCs $\left(10^{-9}, 10^{-8}, 10^{-7}, 10^{-6}\right.$ and $\left.10^{-5} \mathrm{M}\right)$ for $24 \mathrm{~h}$ resulted in a significant increase in cell proliferation at certain concentrations in a dose-dependent manner compared with the control (Fig. 2A-E). An increasing effect on cell proliferation was shown in the treatments with OP (over $10 \mathrm{nM}$ ) and $\mathrm{NP}$ (over $100 \mathrm{nM}$ ) as demonstrated in Figs. 2A and B. In addition, treatment with BPA and MXC resulted in a significant proliferative effect in a dosedependent manner (over $100 \mathrm{nM}$ BPA and over $1 \mu \mathrm{M}$ MXC) as shown in Figs. 2C and D. After treatment with E2 as a positive control, cell proliferation was dose-dependently increased with the $10^{-11}, 10^{-9}$ and $10^{-7} \mathrm{M}$ concentrations of E2 (Fig. 2E). These results indicate that the EDCs induced an estrogenic effect in terms of stimulation of cell growth as E2 did in an E2-dependent ovarian cancer cell line.

To investigate the relevance of the estrogen-induced signal path- way in the cell proliferation, the cells were pretreated with ICI 182780 (ICI; $0.1 \mu \mathrm{M}$ ), an ER $\alpha$ and $\mathrm{ER} \beta$ antagonist, for $20 \mathrm{~min}$ and were then treated with EDCs $\left(10^{-5} \mathrm{M}\right)$ or E2 $\left(10^{-7} \mathrm{M}\right)$. ICI 182780 pretreatment reversed E2-induced cell proliferation in these cells as seen in Fig. 3. In addition, pretreatment with ICI 182780 significantly attenuated EDC-induced cell proliferation (Fig. 3). These results suggest that the ER pathway is involved in EDC-induced cell proliferation in this estrogen-responsive cell line, BG-1.

\section{Effect of EDCs on ERE activity}

The ability of EDCs to activate ER-mediated transcription in BG-1 cells was further measured. The cells were transfected with the reporter plasmid ERE-tk-Luc and then treated with BPA, MXC, OP and NP at two increasing concentrations $\left(10^{-6}\right.$ and $\left.10^{-5} \mathrm{M}\right)$ and E2 $\left(10^{-7} \mathrm{M}\right)$ as a positive control. Under these conditions, BPA stimulated the transcriptional activity of ERE in a dose-dependent manner (Fig. 4A). OP and NP also increased ERE activity at similar level for ERE recruitment as that observed in BPA, but their effects do not appear to be dose-dependent as seen in Fig. 4A. Although a high concentration of MXC $\left(10^{-5} \mathrm{M}\right)$ induced significant ERE activity, treatment with MXC produced much less ERE activity compared with the other EDCs. These results suggest that EDCs, similar to E2, have stimulating effects on ERE activity and activate the ER-mediated pathway at the transcriptional level. To further confirm that the EDC-induced effect on the activity of ERE is mediated via ERs, the cells were pretreated with ICI 182780 (0.1 $\mu \mathrm{M})$, an antagonist of ER. Treatment with ICI 182780 blocked E2 $\left(10^{-7} \mathrm{M}\right)$ - and EDC $\left(10^{-5} \mathrm{M}\right)$-induced ERE activity in BG-1 cells as demonstrated in Fig. 4B. The antagonistic effect of ICI 182780 suggests that EDC-induced ERE promoter transcriptional activity may be mediated by ERs.

\section{Activation of MAPK by BPA}

To investigate whether EDCs induce activation of mitogen-activated protein kinase (MAPK) in ovarian cancer cells, BG-1 cells were treated with increasing concentrations of BPA for 15 min. The phosphorylation of ERK1/2 and p38 was examined using antibodies targeting phosphorylated-ERK1/2 (P-ERK1/2) and phosphorylated-p38 (P-p38). Treatment with BPA at increasing concentrations induced activation of ERK1/2 and p38 MAPK in a dose-dependent manner and maximally increased level was observed at $1 \mu \mathrm{M}$ (Fig. 5). The total-ERK1/2 (T-ERK1/2, activated plus inactivated forms) and total-p38 levels were not affected by treatment with BPA. These results indicate that BPA induced the activation of ERK1/2 and p38 via a non-genomic pathway (within $15 \mathrm{~min}$ ) in the ovarian cancer cells as shown in Fig. 5.

\section{Effect of BPA-induced MAPK activation on cell proliferation}

To further elucidate the relevance of the ERK1/2 and p38 signaling pathways in xenoestrogen- and E2-induced cell growth of BG1 cells, specific inhibitors, PD98059 (an MEK inhibitor) or SB203580 (a p38 inhibitor), were added $1 \mathrm{~h}$ prior to E2 or BPA treatment in a dose-dependent manner. Treatment with PD98059 or SB203580 alone at the doses of $10^{-6}$ and $10^{-5} \mathrm{M}$ did not alter the cell growth of BG-1 cells as shown in Figs. 6A and B. However, treatment with BPA $\left(10^{-5} \mathrm{M}\right)$ or $\mathrm{E} 2\left(10^{-7} \mathrm{M}\right)$ in the presence of 
A

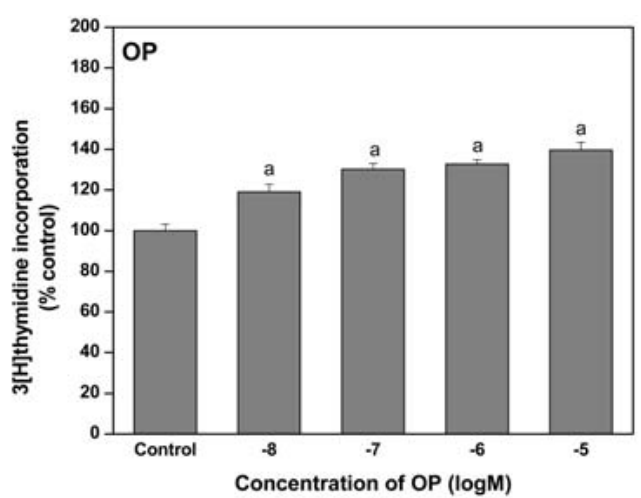

B

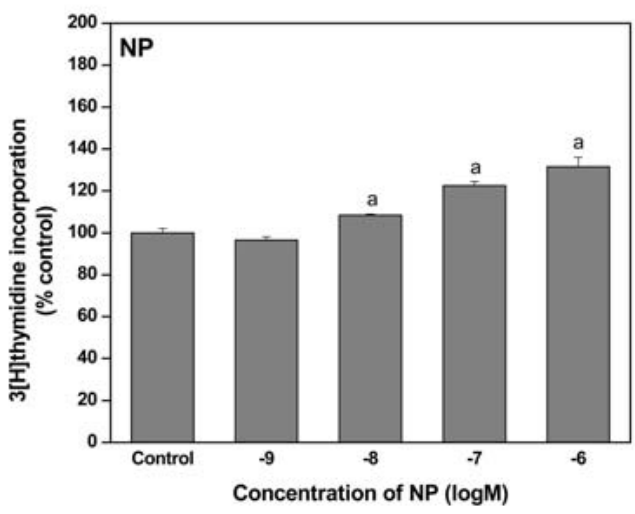

C

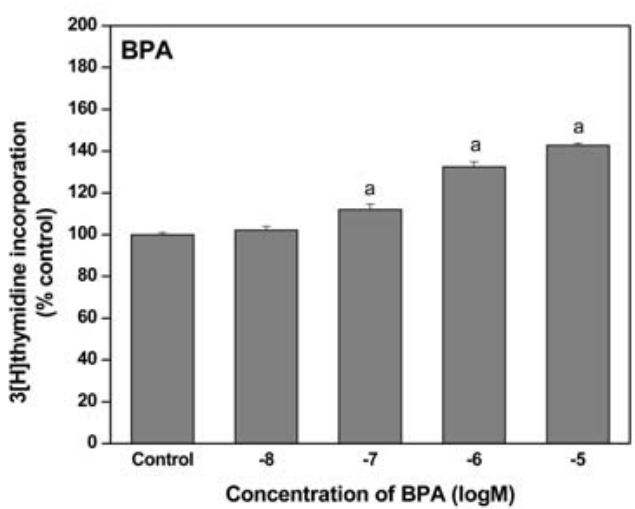

these inhibitors at these doses resulted in stimulation of cell growth in BG-1 cells that was similar to that of the BPA alone treatment (Fig. 6). Co-treatment of BG-1 cells with PD98059 or SB203580 at a high concentration $\left(10^{-4} \mathrm{M}\right)$ resulted in a non-specific reduction in cell growth compared with the untreated controls as shown in Fig. 6.

\section{Discussion}

EDCs are considered to be xenoestrogens that mimic the effect(s) of estrogen, but a previous study demonstrated that some EDCs do not act through ERs, suggesting that a non-genomic effect is part of the mechanism of EDCs [23]. In addition, it has been reported that ERs are not involved in MXC-induced mRNA expres-
D

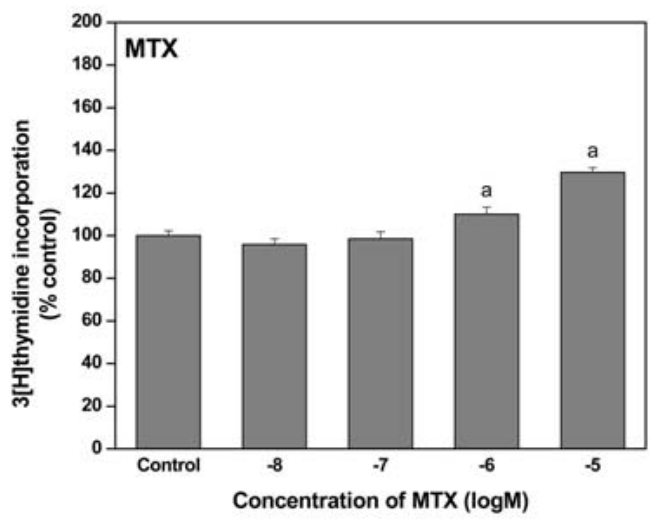

E

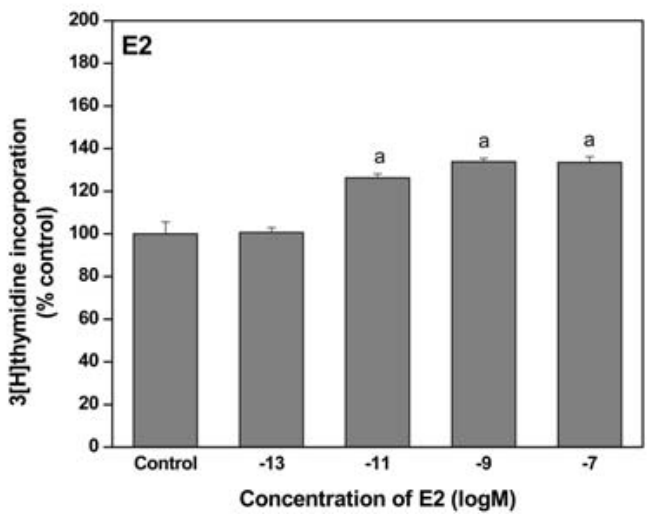

Fig. 2. Effect of xenoestrogens, including BPA, MTX, OP and NP, on cell proliferation in the absence or presence of ICI 182780 (ICI). BG-1 cells were treated with increasing concentrations $\left(10^{-8} \mathrm{M}-10^{-5} \mathrm{M}\right)$ of OP (A), NP (B), BPA (C), MXC (D) or $\mathrm{E} 2\left(\mathrm{E} ; 10^{-7} \mathrm{M}\right)$ for $24 \mathrm{~h}$. The proliferative index was measured by a thymidine incorporation assay. Values are means \pm SD for three individual experiments, each with triplicate samples. a, $\mathrm{P}<0.05$ compared with control. sion [14]. To investigate whether EDCs act through ER-ERE complex , we transiently transfected BG-1 cells with an EREluciferase reporter construct. As expected, treatment with E2 and BPA increased the transcriptional activity of ERE in a dose-dependent manner, and treatment with MXC had less effect on ERE activity compared with the other treated groups. OP and NP also increased ERE activity significantly, but did not show a dosedependent response, indicating that the level of EDC-induced EREactivity and the mechanism involved in EDC-induced ERE activity varies in different types of EDCs. Subsequently, we further investigated the direct involvement of ERs in EDC-induced ERE activation. Pretreatment with ICI 182780 completely abolished E2, BPA, OP and NP-induced ERE activity in BG-1 cells, suggesting that EDC-induced ERE promoter activity appears to be mainly 


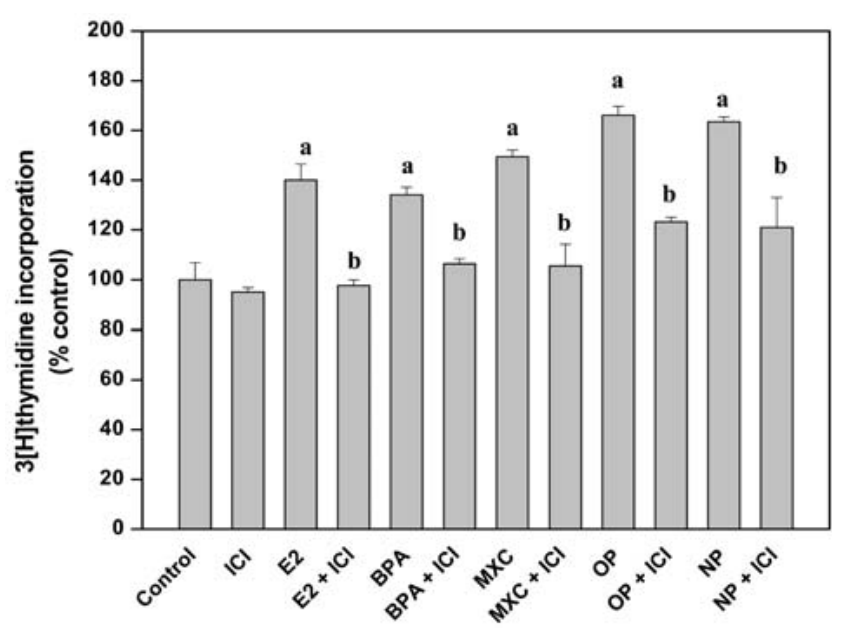

Fig. 3. The effect of ICI 182780 (ICI) on xenoestrogen-induced cell proliferation in BG-1 cells. BG-1 cells were treated with BPA $\left(10^{-5} \mathrm{M}\right)$, MXC $\left(10^{-5} \mathrm{M}\right)$, OP $\left(10^{-5} \mathrm{M}\right)$, NP $\left(10^{-5} \mathrm{M}\right)$ or E2 $\left(10^{-7}\right.$ $\mathrm{M})$ in the presence or absence of ICI $182780\left(10^{-7} \mathrm{M}\right)$ for $24 \mathrm{~h}$. The proliferative index was measured by a thymidine incorporation assay. Values are means \pm SD for three individual experiments, each with triplicate samples. a, $\mathrm{P}<0.05$ compared with control; b, $\mathrm{P}<0.05$ compared with each xenoestrogen treatment only.

mediated by ER-ERE complex in ovarian cancer cells.

Previous reports have also shown that EDCs might present human health risks and result in cell transformation, which may increase the risk of cancer incidence [3, 4, 8]. Furthermore, EDCs, i.e., BPA, OP, NP and MXC, are known to exhibit estrogenic activities and increase the growth of ovarian cancer cells [24]. In order to examine whether these EDCs have a proliferative effect on ovarian cancer cells, an E2-dependent ovarian cancer cell line, BG-1 cells, was treated with EDCs. Treatment with BPA, OP, NP and MXC increased cell growth in these cells. These results are consistent with the previous reports showing that E2 and EDCs induced cell growth in BG-1 cells [25]. However, no significant difference was observed in the groups of BPA, MXC, OP and NP at lower doses compared to E2-treated group, suggesting that they weakly mimic the effect of E2 activity on cell proliferation in ovarian cancer cells due to the lower binding affinity of EDCs to ERs (100010,000 -fold) than E2 [26, 27]. ERs account for most of the EDCinduced mechanism causing endocrine-related disorders [28], suggesting that ERs are involved in the EDC-induced growth in ovarian cancer cells. ERs, nuclear transcription factors, play an important role in mediating the genomic action of the steroid hormone E2 [29]. It has been reported that EDCs exert their actions genomically [30] or non-genomically [31]. It has also been reported that ERs in the plasma membrane are involved in the nongenomic effect of E2 [32] and that ER $\alpha$ mediates the non-genomic signaling pathway of E2 in an ER $\alpha$ positive cell line, BG-1 [33]. To investigate whether ERs are mediated in EDC-induced cell proliferation in ovarian cancer cells, the cells were pretreated with ICI 182780, an estrogen antagonist, prior to BPA, OP, NP and MXC treatment. Pretreatment with ICI 182780 significantly blocked
$\mathbf{A}$

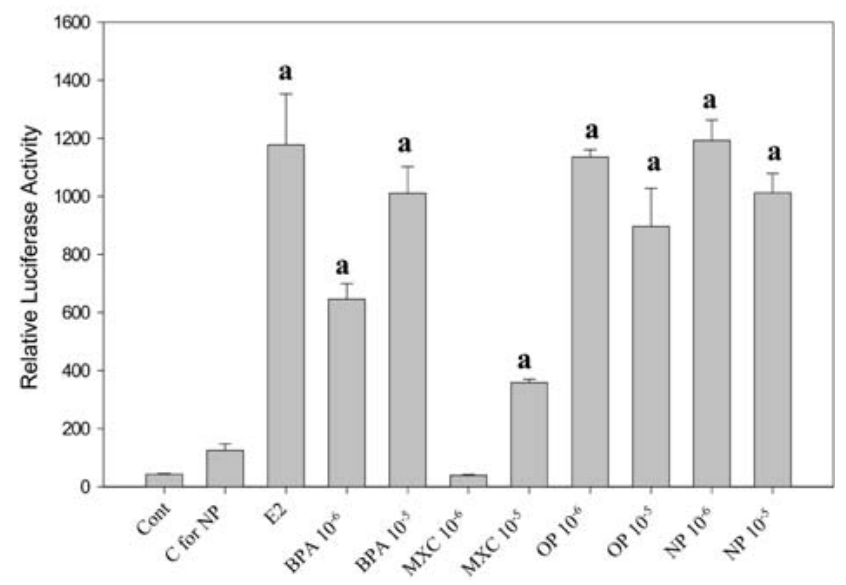

B

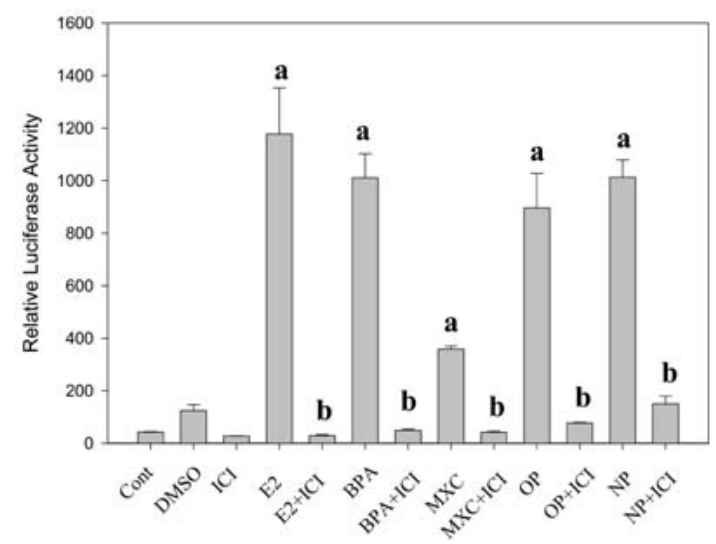

Fig. 4. Regulation of human ERE-tk luciferase vector activity by estrogenic compounds in the absence or presence of ICI 182780. The BG-1 cells were transiently transfected with ERE-tk-Luc and treated with BPA, MXC, OP and NP in a dose-dependent manner (A). In addition, the cells were treated with vehicle (control); 1 $\mu \mathrm{M}$ of E2; $10 \mu \mathrm{M}$ of BPA, MXC, OP and NP; and/or co-treated with ICI 182780 (B). The RSV-Lac Z vector was co-transfected to normalize for varying transfection efficiencies. Values represent means \pm SD from duplicate assays in three separate experiments. a, $\mathrm{P}<0.01$ compared with control; b, $\mathrm{P}<0.05$ compared with each xenoestrogen treatment only.

EDC/E2-induced proliferation in BG-1 cells.

The expression of ER $\alpha$ and ER $\beta$, two types of ERs, is different in most tissue types [34], and these two receptors differentially activate target genes under different circumstances [35]. It is known that ER $\alpha$ accounts for the main mRNA expression of ERs in ovarian cancer cell lines. On the other hand, $\mathrm{ER} \beta$ is dominantly expressed in normal ovaries [36] and is involved in induction of apoptosis or anti-tumoral effects in ovarian cancer cells [37]. Previous studies indicate that the EDC-induced estrogenic effect is mediated through ER $\alpha$ in an animal model [38], suggesting that 


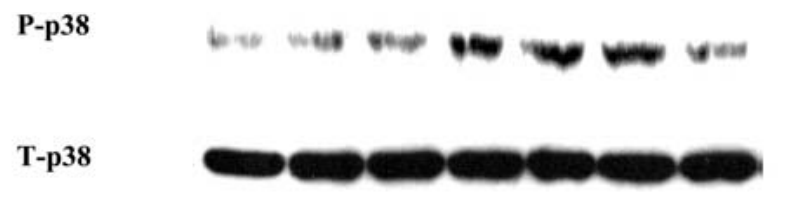

P-ERK1/2

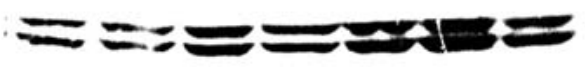

T-ERK1/2

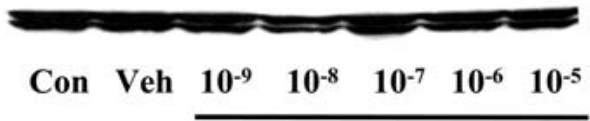

Concentration of BPA (M)

Fig. 5. Dose-dependent effect of EDCs on the activation of ERK1/2 and p38 in an ovarian cancer cell line. BG-1 cells were cultured and treated with xenoestrogens for $15 \mathrm{~min}$ in a dose-dependent manner. Lanes 1 and 2 contain the extracted proteins of the control and vehicle. The total levels of ERK1/2 and p38 (TERK1/2 and T-p38) and phosphorylated levels of ERK1/2 and p38 (P-ERK1/2 and P-p38) were analyzed by immunoblot assay.

high concentrations of EDCs may increase cell growth by binding to $\mathrm{ER} \alpha$. However, further research is required to clarify the precise roles of $\mathrm{ER} \alpha$ and $\mathrm{ER} \beta$ in EDC-induced cell proliferation.

In the previous studies, BPA, OP and NP induced activation of ERK1/2 in MCF-7 cells [39]. A recent study indicated that E2 induced activation of p38 via non-genomic action [40]. However, there is little information available concerning the non-genomic effect of EDCs on ovarian cancer cells, and the issue of whether EDCs exert a non-genomic effect in ovarian cancer cells remains obscure. Thus, the MAPK activation was examined by immunoblot analysis using a phospho-specific ERK1/2 and p38 MAPK antibody following treatment with BPA. Treatment with BPA induced the activation of ERK1/2 and p38 in a dose-dependent manner, suggesting that a non-genomic effect may also be involved in EDC-induced cellular responses in ovarian cancer cells. However, activation of ERK1/2 and p38 MAPK appears to be decreased at high concentration of BPA $(10 \mu \mathrm{M})$, suggesting that BPA might be involved in induction of MAPK phosphatase at this concentration. To elucidate the signaling pathway involved in this increasing proliferation as a result of EDCs, BG-1 cells were pretreated with specific inhibitors of MEK (PD98059) and p38 MAPK (SB203580) in a dose-dependent manner and were then treated with E2 or BPA. Treatment with PD98059 or SB203580 alone reduced cell proliferation in a dose dependent manner due to the blocking of MAPK activation. However, inhibition of MAPK activation by these inhibitors does not seem to affect BPA or E2induced cell proliferation since treatment with EDC/E2 in the presence of these inhibitors increased cell proliferation compared with the groups treated with PD98059 or SB203580 alone at all concentrations. These results suggest that activation of ERK1/2 and p38 MAPK is not involved in stimulation of E2 or EDC-induced cell
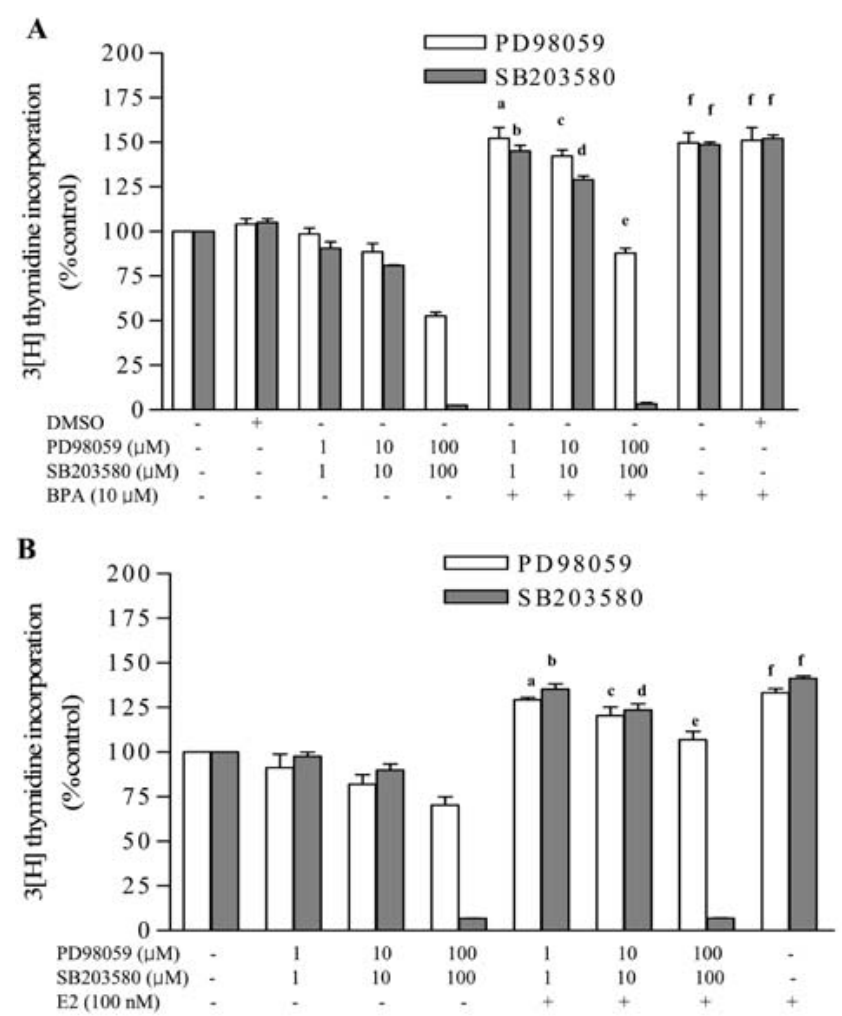

Fig. 6. The effect of ERK1/2 and p38 MAPK activation by E2 or BPA on ovarian cancer cell proliferation. BG-1 cells were pretreated with PD98059 or SB203580 prior to treatment with E2 $(100 \mathrm{nM})$ or BPA $(10 \mu \mathrm{M})$ [-BPA $\rightarrow$ without BPA; +BPA $\rightarrow$ with BPA; $\mathrm{E} 2 \rightarrow$ without E2; +E2 $\rightarrow$ with E2]. To quantify DNA synthesis, a $\left[{ }^{3} \mathrm{H}\right]$ thymidine incorporation assay was performed as previously described. Each experiment was repeated 3 times $(n=$ 3 ). The values are presented as means \pm SD of three individual experiments. a, $\mathrm{P}<0.05$ vs. PD98059 $(1 \mu \mathrm{M})$ treatment; b, $\mathrm{P}<0.05$ vs. SB203580 $(1 \mu \mathrm{M})$ treatment; c, PD98059 $(10 \mu \mathrm{M})$ treatment; d, $\mathrm{P}<0.05$ vs. SB203580 $(10 \mu \mathrm{M})$ treatment; e, PD98059 $(100 \mu \mathrm{M})$ treatment; $\mathrm{f}, \mathrm{P}<0.05$ vs. control.

growth in estrogen-responsive ovarian cancer cells. Further research is necessary to explain the possible role of the EDCinduced MAPK activation in ovarian cancer cells.

Based on the results presented herein, EDC-induced ovarian cancer cell growth is mediated by ERs. In addition, ERE activation is involved in EDC-induced ER activity, suggesting that EDCs may share the components of a common pathway with E2 to induce cell proliferation; however, EDC-activated MAPK is unlikely to be involved in EDC-induced cell proliferation in estrogen-responsive ovarian cancer cells, BG-1.

\section{Acknowledgments}

This work was supported by the Canadian Foundation for Women's Health (CFWH; to KCC), the StartUp Fund from Faculty of Medicine, University of British Columbia (to KCC), and the Canadian Institutes of Health Research (to PCKL). In addition, this 
work was supported, in part, by the National Cancer Institute of Canada (NCIC; to KCC).

\section{References}

1. Schally AV, Comaru-Schally AM, Nagy A, Kovacs M, Szepeshazi K, Plonowski A, Varga JL, Halmos G. Hypothalamic hormones and cancer. Front Neuroendocrinol 2001; 22: 248-291.

2. Cramer DW, Welch WR. Determinants of ovarian cancer risk. II. Inferences regarding pathogenesis. J Natl Cancer Inst 1983; 71: 717-721.

3. Bencko V. Human exposure to endocrine disrupters: carcinogenic risk assessment. Folia Histochem Cytobiol 2001; 39 (Suppl 2): 24-25.

4. Brevini TA, Zanetto SB, Cillo F. Effects of endocrine disruptors on developmental and reproductive functions. Curr Drug Targets Immune Endocr Metabol Disord 2005; 5: $1-10$.

5. Iguchi T, Watanabe H, Katsu Y. Application of ecotoxicogenomics for studying endocrine disruption in vertebrates and invertebrates. Environ Health Perspect 2006; 114 (Suppl 1): 101-105.

6. Daston GP, Cook JC, Kavlock RJ. Uncertainties for endocrine disrupters: our view on progress. Toxicol Sci 2003; 74: 245-252

7. Yurino H, Ishikawa S, Sato T, Akadegawa K, Ito T, Ueha S, Inadera H, Matsushima K. Endocrine disruptors (environmental estrogens) enhance autoantibody production by B1 cells. Toxicol Sci 2004; 81: 139-147.

8. Colborn T, vom Saal FS, Soto AM. Developmental effects of endocrine-disrupting chemicals in wildlife and humans. Environ Health Perspect 1993; 101: 378-384.

9. Maffini MV, Rubin BS, Sonnenschein C, Soto AM. Endocrine disruptors and reproductive health: the case of bisphenol-A. Mol Cell Endocrinol 2006; 254-255: 179-186.

10. Wozniak AL, Bulayeva NN, Watson CS. Xenoestrogens at picomolar to nanomolar concentrations trigger membrane estrogen receptor-alpha-mediated $\mathrm{Ca}^{2+}$ fluxes and prolactin release in GH3/B6 pituitary tumor cells. Environ Health Perspect 2005; 113: 431-439.

11. Markey CM, Rubin BS, Soto AM, Sonnenschein C. Endocrine disruptors: from Wingspread to environmental developmental biology. J Steroid Biochem Mol Biol 2002; 83: 235-244.

12. Staples CA, Dorn PB, Klecka GM, O'Block ST, Branson DR, Harris LR. Bisphenol A concentrations in receiving waters near US manufacturing and processing facilities. Chemosphere 2000; 40: 521-525.

13. Steinmetz R, Mitchner NA, Grant A, Allen DL, Bigsby RM, Ben-Jonathan N. The xenoestrogen bisphenol A induces growth, differentiation, and c-fos gene expression in the female reproductive tract. Endocrinology 1998; 139: 2741-2747.

14. Ghosh D, Taylor JA, Green JA, Lubahn DB. Methoxychlor stimulates estrogenresponsive messenger ribonucleic acids in mouse uterus through a non-estrogen receptor (non-ER) alpha and non-ER beta mechanism. Endocrinology 1999; 140: 35263533.

15. Vazquez-Duhalt R, Ayala M, Marquez-Rocha FJ. Biocatalytic chlorination of aromatic hydrocarbons by chloroperoxidase of Caldariomyces fumago. Phytochemistry 2001; 58: 929-933.

16. Nimrod AC, Benson WH. Environmental estrogenic effects of alkylphenol ethoxylates. Crit Rev Toxicol 1996; 26: 335-364.

17. Isidori M, Lavorgna M, Nardelli A, Parrella A. Toxicity on crustaceans and endocrine disrupting activity on Saccharomyces cerevisiae of eight alkylphenols. Chemosphere 2006; 64: 135-143.

18. Saito I, Onuki A, Seto H. Indoor air pollution by alkylphenols in Tokyo. Indoor Air 2004; 14: 325-332.

19. Kuch HM, Ballschmiter K. Determination of endocrine-disrupting phenolic compounds and estrogens in surface and drinking water by HRGC-(NCI)-MS in the picogram per liter range. Environ Sci Technol 2001; 35: 3201-3206.

20. Cheng CK, Chow BK, Leung PC. An activator protein 1-like motif mediates 17betaestradiol repression of gonadotropin-releasing hormone receptor promoter via an estrogen receptor alpha-dependent mechanism in ovarian and breast cancer cells. Mol Endocrinol 2003; 17: 2613-2629.

21. Kim KY, Choi KC, Auersperg N, Leung PC. Mechanism of gonadotropin-releasing hormone $(\mathrm{GnRH})-\mathrm{I}$ and -II-induced cell growth inhibition in ovarian cancer cells: role of the GnRH-I receptor and protein kinase C pathway. Endocr Relat Cancer 2006; 13 211-220.

22. Geisinger KR, Kute TE, Pettenati MJ, Welander CE, Dennard Y, Collins LA, Berens ME. Characterization of a human ovarian carcinoma cell line with estrogen and progesterone receptors. Cancer 1989; 63: 280-288

23. Waring RH, Harris RM. Endocrine disrupters: a human risk? Mol Cell Endocrinol 2005 244: 2-9.

24. Cunat S, Hoffmann P, Pujol P. Estrogens and epithelial ovarian cancer. Gynecol Oncol 2004; 94: 25-32.

25. Giacalone PL, Daures JP, Ouafik L, Martin PM, Laffargue F, Maudelonde T. Steroids and adrenomedullin growth patterns in human ovarian cancer cells: estrogenicregulation assay. Gynecol Oncol 2003; 91: 651-656.

26. Schmitt E, Dekant W, Stopper H. Assaying the estrogenicity of phytoestrogens in cells of different estrogen sensitive tissues. Toxicol In Vitro 2001; 15: 433-439.

27. Mueller SO, Kling M, Arifin Firzani P, Mecky A, Duranti E, Shields-Botella J Delansorne R, Broschard T, Kramer PJ. Activation of estrogen receptor alpha and ERbeta by 4-methylbenzylidene-camphor in human and rat cells: comparison with phyto- and xenoestrogens. Toxicol Lett 2003; 142: 89-101.

28. Choi KC, Jeung EB. The biomarker and endocrine disruptors in mammals. J Reprod Dev 2003; 49: 337-345.

29. Mosselman S, Polman J, Dijkema R. ER beta: identification and characterization of a novel human estrogen receptor. FEBS Lett 1996; 392: 49-53.

30. Ropero AB, Alonso-Magdalena P, Ripoll C, Fuentes E, Nadal A. Rapid endocrine disruption: environmental estrogen actions triggered outside the nucleus. I Steroid Biochem Mol Biol 2006; 102: 163-169.

31. Harris RM, Kirk CJ, Waring RH. Non-genomic effects of endocrine disrupters: inhibition of estrogen sulfotransferase by phenols and chlorinated phenols. Mol Cell Endocrinol 2005; 244: 72-74

32. Edwards DP. Regulation of signal transduction pathways by estrogen and progesterone. Annu Rev Physiol 2005; 67: 335-376.

33. Albanito L, Madeo A, Lappano R, Vivacqua A, Rago V, Carpino A, Oprea TI, Prossnitz ER, Musti AM, Ando S, Maggiolini M. G protein-coupled receptor 30 (GPR30) mediates gene expression changes and growth response to 17beta-estradiol and selective GPR30 ligand G-1 in ovarian cancer cells. Cancer Res 2007; 67: 1859-1866.

34. Couse JF, Lindzey J, Grandien K, Gustafsson JA, Korach KS. Tissue distribution and quantitative analysis of estrogen receptor-alpha (ERalpha) and estrogen receptor-beta (ERbeta) messenger ribonucleic acid in the wild-type and ERalpha-knockout mouse Endocrinology 1997; 138: 4613-4621.

35. Paech K, Webb P, Kuiper GG, Nilsson S, Gustafsson J, Kushner PJ, Scanlan TS. Differential ligand activation of estrogen receptors ERalpha and ERbeta at AP1 sites. Science 1997; 277: 1508-1510.

36. Pujol P, Rey JM, Nirde P, Roger P, Gastaldi M, Laffargue F, Rochefort H, Maudelonde T. Differential expression of estrogen receptor-alpha and -beta messenge RNAs as a potential marker of ovarian carcinogenesis. Cancer Res 1998; 58: 5367-5373.

37. Treeck O, Pfeiler G, Mitter D, Lattrich C, Piendl G, Ortmann O. Estrogen receptor \{beta\}1 exerts antitumoral effects on SK-OV-3 ovarian cancer cells. J Endocrinol 2007 193: 421-433.

38. Dang VH, Choi KC, Jeung EB. Tetrabromodiphenyl ether (BDE 47) evokes estrogenicity and calbindin-D9k expression through an estrogen receptor-mediated pathway in the uterus of immature rats. Toxicol Sci 2007; 97: 504-511.

39. Cobb MH, Goldsmith EJ. How MAP kinases are regulated. J Biol Chem 1995; 270: 14843-14846.

40. Seval Y, Cakmak H, Kayisli UA, Arici A. Estrogen-mediated regulation of p38 mitogen-activated protein kinase in human endometrium. J Clin Endocrinol Metab 2006; 91 2349-2357. 